\title{
Optimization of Solid State Fermentation and Leaching Process Parameters for Improvement Xylanase Production by Endophytic Streptomyces sp. ESRAA-301097
}

\author{
Mervat MA El-Gendy ${ }^{1 *}$ and Ahmed MA El-Bondkly ${ }^{2}$
}

${ }^{1}$ Chemistry of Natural and Microbial Products Department, National Research Centre, Dokki, Giza, Egypt

${ }^{2}$ Genetics and Cytology Department, National Research Centre, Dokki, Giza, Egypt

\begin{abstract}
In the course of our searching program on the microbial endophytes of medical plants (Cympobogon proximus, Anethum graveolens, Artemisia judaica and Corchorus olitorius), the endophytic strain Streptomyces sp. ESRAA-301097 derived from Cympobogon proximus proved to be the hyper xylanase producer. Screening of various locally available agro-industrial residues as substrate support for xylanase production under SSF exhibited a mixture of wheat bran (WB); sugarcane bagasse (SCB) with corncob (CC) at a ratio of 0.5:1:1 as the efficient inducer for the induction of ESRAA-301097 xylanase production as it gave the highest enzyme productivity (2364 $\left.\mathrm{Ugds}^{-1}\right)$ at the 4th day of fermentation when compared to individual WB, SCB or CC (1167, 1241 or $\left.1404 \mathrm{Ugds}^{-1}\right)$ after 3, 4 and 4 days of incubation. Xylanase production was enhanced to $3819 \mathrm{Ugds}^{-1}$ after optimizing the physical process parameters including temperature $30-40^{\circ} \mathrm{C}, \mathrm{pH} 7.0$, an inoculum level of $10^{7}$ spore $\mathrm{gds}^{-1}, 80-85 \%$ initial moisture content and substrate particle size of $800 \mu \mathrm{m}$. An overall $23.96 \%$ increase in enzyme production was attained with a mixture of soybean and corn steep solid as a nitrogen source but no enhancement was obtained with any of carbon or metal supplementation. Whereas xylanase yield was elucidated to $5709.2 \mathrm{Ugds}^{-1}$ by adding Tween 20 , SDS repressed its production to $750.29 \mathrm{Ugds}^{-1}$. The optimized leaching parameters for effective extraction of xylanase $\left(6312.45 \mathrm{Ugds}^{-1}\right)$ from the fermented solid mixture were found to be citrate buffer $(0.1 \mathrm{M}, \mathrm{pH} 4.0)$ containing $0.2 \%$ Tween 80 as leaching agent, extractant volume 1:8-1:10 (w/v), soaking time $120 \mathrm{~min}$, leaching $\mathrm{pH} 4$ and leaching temperature $50^{\circ} \mathrm{C}$ under agitation at $150 \mathrm{rpm}$. The overall level of 44.61 -fold purification of Streptomyces sp. ESRAA-301097 and xylanase recovery $32.52 \%$ were achieved with specific activity of $493.48 \mathrm{Umg}^{-1}$. The purified enzyme showed a single protein band on SDS-PAGE indicating the monomeric nature of the enzyme with molecular weight $\sim 31.5 \mathrm{kDa}$. Furthermore, whereas the inhibitors of cysteine protease $(1,10$-phenanthroline and Dithiothreitol), metaloprotease (EDTA and EGTA) and thioprotease (iodoacetamide and p-chloromercuribenzoate) had no to minor effects on xylanase activity, the serine protease inhibitor (PMSF) markedly decreased it.
\end{abstract}

Keywords: Endophytic Streptomyces; Xylanase; Optimization; Purification; Characterization

\section{Introduction}

Xylan constitutes 20 to $40 \%$ of higher plants and agricultural wastes dry weight. Microbial xylanases are of increasing interest due to their potential in biotechnological applications as converting of lignocelluloses in industry to sugar; ethanol or other useful substances, improving the nutritional quality of silage or green feed, deinking processes of waste papers and liquefying the fruits and vegetables [1]. The multifunctional xylanolytic enzyme system is wide spread among fungi [2] and bacteria but great potential of xylan assimilating Actinomycetes can be attributed to highly activity, thermo-stability and free of substantial cellulase activity [3]. One relatively unexplored and new microbial niche is the inner tissues of higher plants, creating an enormous biodiversity that can be isolated after surface sterilization $[4,5]$. However in vitro, various endophytes exhibited high ability to produce various enzymes of biotechnological importance with new characters such as endophytic Micromonospora sp. Aya 2000, the recombinant strain Tahrir-25, Aspergillus sp. Jan 25, and Aspergillus Sp. NRCF5 that have been reported as potent producer for the highly active keratinase, cellulase, glucoamylase, and xylanase enzymes with new characters [6-9]. In spite of the enormous industrial importance, the production of xylanase was hindered by the high cost of production [10]. In order to curtail the production cost, one should use inexpensive substrates and follow an efficient fermentation process as solid state fermentation (SSF), which features by higher productivity with better exploitation of agro residues as substrates to achieve the economic viability of these otherwise waste resources as well as safeguard the environment [10]. The goals of the recent study are: i) Evaluation of some Egyptian medical plants as enormous source for endophytic actinobacteria, especially those with xylanolytic activity ii) Cost effective production of xylanase by the hyper endophytic producer, Streptomyces sp. ESRAA-301097 iii) Optimization of SSF and leaching process parameters for maximum yield of xylanase iv) Purification and characterization of xylanase produced by Streptomyces sp. ESRAA-301097.

\section{Materials and Methods}

Birchwood xylan (Sigma Co.) was used for enzyme assay. Each fermented matter as wheat bran (WB), rice bran (RB), sugarcane

${ }^{*}$ Corresponding author: Mervat M. A. El-Gendy, Chemistry of Natural and Microbial Products Department, National Research Centre, Dokki, Giza, Egypt, Tel: +20 2 33371211; E-mail: m_morsy_70@yahoo.com

Received March 05, 2014; Accepted March 24, 2014; Published March 28, 2014

Citation: El-Gendy MMA, El-Bondkly AMA (2014) Optimization of Solid State Fermentation and Leaching Process Parameters for Improvement Xylanase Production by Endophytic Streptomyces sp. ESRAA-301097. J Microb Biochem Technol 6: 154-166. doi:10.4172/1948-5948.1000137

Copyright: ( $2014 \mathrm{El-Gendy} \mathrm{MMA,} \mathrm{et} \mathrm{al.} \mathrm{This} \mathrm{is} \mathrm{an} \mathrm{open-access} \mathrm{article} \mathrm{distributed}$ under the terms of the Creative Commons Attribution License, which permits unrestricted use, distribution, and reproduction in any medium, provided the original author and source are credited 
Citation: El-Gendy MMA, El-Bondkly AMA (2014) Optimization of Solid State Fermentation and Leaching Process Parameters for Improvement Xylanase Production by Endophytic Streptomyces sp. ESRAA-301097. J Microb Biochem Technol 6: 154-166. doi:10.4172/19485948.1000137

bagasse (SCB), corncob (CC), rice straw (RS), wheat straw (WS), barely bran (BB), banana stalk (BS), sorghum stalk (SS) and maize stalk (MS) was obtained from local supplier, stripped, dried, grinded, sieved and evaluated as substrate support.

\section{Enzyme assay}

Xylanase activity was assayed according to the method of Bailey et al. [11] using $1 \%$ birchwood xylan in $0.01 \mathrm{M}$ phosphate buffer ( $\mathrm{pH}$ 7.0). The release of reducing sugars was determined using the 3 , 5- dinitrosalicylic acid (DNS) method [12]. One unit (U) of xylanase was defined as the amount of enzyme required to liberate $1 \mu \mathrm{mol}$ of xylose from xylan in $1 \mathrm{~min}$ under the assay conditions. All experiments have been performed in triplicates. Xylanase production in SSF was expressed as $\mathrm{U} / \mathrm{g}$ dry solid substrate $\left(\mathrm{Ugds}^{-1}\right)$ but in submerged fermentation (SMF) in terms of $\mathrm{U} / \mathrm{ml}\left(\mathrm{Uml}^{-1}\right)$.

\section{Isolation of plant-derived endophytic Actinomycetes}

Each organ (roots, stems and leaves) of the collected Egyptian medicinal plants Cympobogon proximus (halfabar), Anethum graveolens (dill), Artemisia judaica (shih balady) and Corchorus olitorius (malukhiyah) were surface sterilized and sectioned into small fragments as previously described [5]. These surface sterilized tissue segments were plated onto three different isolation media, actinomycetes isolation agar (AIA), dextrose yeast extract malt extract agar (DYMA) [13] and xylan agar medium (XAM) [14], which incubated at $28^{\circ} \mathrm{C}$ for 3 weeks until the selected single colonies that exhibited similar morphological features of Actinomycetes growing out the plated segments. Endophytic actinobacterial isolates obtained were maintained at $4^{\circ} \mathrm{C}$ in the Chemistry of Natural and Microbial Products Department at National Research Center.

\section{Screening of xylanase-producing Actinomycetes}

Xylanolytic isolates were detected by growing on selective xylanagar medium at $\mathrm{pH} 7.0$ and $28^{\circ} \mathrm{C}$ for 5 days and then stained with Congo red solution [14]. Xylanolytic isolates were evaluated on the basis of the diameter of the xylan digestion halo zone as: weak xylanase producer (8-14 mm); moderate xylanase producer (15-24 $\mathrm{mm}$ ) and high xylanase producer $(25-35 \mathrm{~mm})$. The strains displaying the biggest xylan digestion halo were secondary screened in $250 \mathrm{ml}$ Erlenmeyer flasks containing $50 \mathrm{ml}$ of xylan broth medium at $30^{\circ} \mathrm{C}$ and $\mathrm{pH} 7.0$ in a rotary shaker at $180 \mathrm{rpm}$ for five days. The endophytic isolate demonstrating the highest xylanase activity in primary and secondary screening was selected for further studies.

\section{Characterization of xylanase hyper-producer isolate}

Characterization of the hyper-xylanase producing isolate, ESRAA-301097, was done through polyphasic characterization (phenotypic, chemotypic and genotypic features).

\section{Phenotypic and chemotypic characterization}

The analysis of phenotypic and chemotypic characteristics was done according to the diagnostic key of Szabo et al. [15], Williams et al. [16] and Shirling and Gottlieb[17]. Determination of the isomer of diaminopimelic acid (DAP) and the whole-cell sugar pattern was carried out as described by Hasegawa et al. [18], but fatty acid methyl esters were prepared by the trimethylsulphonium hydroxide method [19]. Phospholipids analysis was determined according to Lechevalier et al. [20] and Minnikin et al. [21]. The base composition of genomic DNA was determined by the method of Mandel and Marmur [22].

\section{Genomic DNA preparation and 16S rDNA sequencing}

Genomic DNA was extracted and purified using the QIAGEN DNeasys Tissue Kit following the manufacturer's protocol for Grampositive bacteria. Amplification of ribosomal DNA was performed using puReTaq ${ }^{\mathrm{TM}}$ Ready-To-Go ${ }^{\mathrm{TM}}$ PCR Beads (GE Healthcare). For amplification of the nearly complete $16 \mathrm{~S}$ rRNA gene the eubacterial primers $27 \mathrm{f}$ and $1492 \mathrm{r}$ were used [23]. The conditions for this PCR were applied according to El-Bondkly et al. [24]. PCR products were checked for correct length on a $1 \%$ Tris-borate-EDTA (TBE) agarose gel (1\% agarose, $8.9 \mathrm{mM}$ Tris, $8.9 \mathrm{mM}$ borate, $0.2 \mathrm{mM}$ EDTA), stained with ethidium bromide and visualized under UV illumination. Purification of PCR products and determination of sequences using the $16 \mathrm{~S} \mathrm{rDNA}$ specific primers $342 \mathrm{f}, 534 \mathrm{r}$, $790 \mathrm{f}$ and $1492 \mathrm{r}$ were done. Sequence data were edited with Lasergene Software SeqMan (DNAStar Inc.). Next relatives were determined by comparison to $16 \mathrm{~S}$ rRNA genes in the NCBI GenBank database using BLAST (Basic Local Alignment Search Tool, http://www.ncbi.nlm.nih.gov website) to create a matrix using MEGA6 and ClustalW programs. The tree topologies were evaluated by bootstrap analyses based on 1,000 replications with MEGA6 and phylogenetic trees were inferred using the neighbor-joining method. The complete $16 \mathrm{~S}$ rDNA sequences of the hyper-xylanase producing strain ESRAA-301097 have been deposited in GenBank database under the Accession numbers KF877333.

\section{Xylanase production under submerged fermentation using agro industrial residues}

The production media (ISP4) supplemented with $1 \%$ wheat bran (WB), rice bran $(\mathrm{RB})$, sugarcane bagasse $(\mathrm{SCB})$, corncob $(\mathrm{CC})$, rice straw (RS), wheat straw (WS), barely bran (BB), banana stalk (BS), sorghum stalk (SS) or maize stalk (MS), individually instead of starch were inoculated with $10^{6}$ spores $\mathrm{ml}^{-1}$ at $\mathrm{pH} 7.0,28^{\circ} \mathrm{C}$ and $180 \mathrm{rpm}$ for 7 days. After fermentation, the culture broth was centrifuged at $4^{\circ} \mathrm{C}$ for $20 \mathrm{~min}$ at 10,000 rpm and the cell free supernatant was used as enzyme source.

\section{Optimization of solid state fermentation (SSF) process parameters}

Solid state fermentation (SSF) process parameters were optimized by adopting search technique varying each parameter independently at the time and subsequently once optimized fixed for each subsequent experimental run as described by El-Gendy [8].

\section{Selection of solid substrate support}

Ten grams of such agro industrial residue mentioned before with a particle size of $600 \mu \mathrm{m}$ moistened at $60 \%(\mathrm{v} / \mathrm{w})$ with phosphate buffer ( $\mathrm{pH} 7.0$ ) were inoculated with $10^{6}$ spores $\mathrm{g}^{-1}$ and incubated at $28^{\circ} \mathrm{C}$ in $250 \mathrm{ml}$ Erlenmeyer flasks to evaluate the impact of each substrate support on xylanase production by Streptomyces sp. ESRAA-301097 versus different incubation periods (1-7 days) under SSF. Furthermore, the impact of mixtures of the best inducers (CC, SCB and WB) with different concentrations on xylanase production was determined. At the end of each experiment the homogenized fermented substrates were suspended in $100 \mathrm{ml}$ of citrate buffer $(0.1 \mathrm{M}$ and $\mathrm{pH} 4)$, shaking at $150 \mathrm{rpm}$ for $120 \mathrm{~min}$ at $45^{\circ} \mathrm{C}$, then centrifuged at $10,000 \mathrm{rpm}$ and $4^{\circ} \mathrm{C}$ for $15 \mathrm{~min}$ and the cell free supernatant was used as enzyme for analysis.

Optimization of physical and nutritional process parameters in SSF

In this study the optimized physical process parameters were 
Citation: El-Gendy MMA, El-Bondkly AMA (2014) Optimization of Solid State Fermentation and Leaching Process Parameters for Improvement Xylanase Production by Endophytic Streptomyces sp. ESRAA-301097. J Microb Biochem Technol 6: 154-166. doi:10.4172/19485948.1000137

incubation temperature $\left(25,28,30,35,40\right.$ and $\left.45^{\circ} \mathrm{C}\right)$, initial $\mathrm{pH}(3.0$, $3.5,4.0,4.5,5.0,5.5,6.0,6.5,7.0,7.5,8.0,9.0$ and 10$)$, inoculum level $\left(1 \times 10^{3}, 1 \times 10^{4}, 1 \times 10^{5}, 1 \times 10^{6}, 1 \times 10^{7}, 1 \times 10^{8}, 1 \times 10^{9}\right.$ and $1 \times 10^{10}$ spores $\left.\mathrm{g}^{-1}\right)$, initial moisture content $(40,50,60,70,75,80,85$ and $90 \%)$ and substrate particle size of $200,400,600,800,1000$ and $2000 \mu \mathrm{m}$. On the other hand, the impact of adding various supplementations to the solid substrate support as carbon sources $(0.5 \% \mathrm{w} / \mathrm{w}$ of glucose, fructose, mannose, maltose, lactose, sucrose, arabinose, galactose and starch), nitrogen sources $(0.2 \% \mathrm{w} / \mathrm{w}$, in terms of available nitrogen) of organic sources (yeast extract, peptone, soybean meal, corn steep solid, casein, urea, phenylalanine, arginine, glutamine and tryptophan) or inorganic nitrogen $\left(\mathrm{NH}_{4} \mathrm{NO}_{3}, \mathrm{NaNO}_{3},\left(\mathrm{NH}_{4}\right) 2 \mathrm{SO}_{4}\right.$ and $\left.\mathrm{NH}_{4} \mathrm{Cl}\right), 0.1 \%$ of metal source $\left(\mathrm{CaCl}_{2}, \mathrm{NaCl}, \mathrm{KCl}, \mathrm{MgCl}_{2}\right.$ and $\left.\mathrm{K}_{2} \mathrm{HPO}_{4}\right)$ and detergent additives (Triton X-100, Tween 20, Tween 80 , sodium dodecylsulfate, sodium tetraborate and Polyethylene glycol) on xylanase production was attempted.

\section{Optimization of leaching process parameters for xylanase from fermented solids}

The leaching parameters were optimized by adopting search technique varying parameters one at the time as described by El-Gendy [8].

\section{Optimization of leaching agent}

The leaching out of xylanase from the fermented mixture was carried out with different extractants, as water, methanol, acetone, butanol, glycerol, $\mathrm{NaCl}(1 \%)$, citrate buffer $(0.1 \mathrm{M}$ at $\mathrm{pH} 4.0$ and $\mathrm{pH}$ 6.0), phosphate buffer (0.1 M, pH 7.0), glycine- $\mathrm{NaOH}$ buffer $(0.1 \mathrm{M}$, $\mathrm{pH} 10.0)$, Tween $80(0.1,0.2$ and $0.3 \%)$ followed by leaching out by citrate buffer $(\mathrm{pH} 4.0,0.1 \mathrm{M})$ contain $0.2 \%$ tween 80 (the best leaching agents) at a ratio of 1 fermenter substrates:10 leaching agent (w/v), $45^{\circ} \mathrm{C}$ and $150 \mathrm{rpm}$ for $120 \mathrm{~min}$.

\section{Optimization of leaaching agent volume, soaking time,} temperature, $\mathrm{pH}$ and physical state of the leaching process

The leaching parameters including the ratio of leaching agent to the fermented substrate (from 1:2 to 1:20 w/v), soaking time $(30,60,90$, $120,150$ and $180 \mathrm{~min})$, leaching $\mathrm{pH}(3,4,5,6,7,8,9$ and 10), leaching temperature $\left(30,40,45,50,55,60\right.$ and $\left.70^{\circ} \mathrm{C}\right)$ and physical state of extraction process (static and agitation at $150 \mathrm{rpm}$ ) were optimized for maximum xylanase leaching out from the fermented solid substrates.

\section{Purification and electrophoresis}

Xylanase of Streptomyces sp. ESRAA-301097 was maximized and leached as described before, the cell debris was removed by filtration under vacuum and the cell-free supernatant was precipitated by $70 \%$ $(\mathrm{w} / \mathrm{v})$ saturated ammonium sulphate, centrifuged at $10000 \mathrm{rpm}$ for 20 min at $4^{\circ} \mathrm{C}$ and the collected precipitate was resuspended in $50 \mathrm{mM}$ phosphate buffer ( $\mathrm{pH} 7.0$ ), dialyzed against the same buffer for $24 \mathrm{~h}$ at $4^{\circ} \mathrm{C}$ and the desalted ammonium sulfate fraction was lyophilized for further purification by chromatography. The lyophilized material was dissolved in $10 \mathrm{ml}$ of phosphate buffer ( $\mathrm{pH} \mathrm{7.0)}$ and loaded on to a DEAE-cellulose chromatographic column $(2.5 \times 40 \mathrm{~cm})$ that had been equilibrated and eluted with $50 \mathrm{mM}$ phosphate buffer containing 0.5 $\mathrm{M} \mathrm{NaCl}$, at a flow rate of $30 \mathrm{ml} / \mathrm{h}$. The xylanase fractions were pooled, concentrated, dialyzed against the same buffer, lyophilized, dissolved in $5.0 \mathrm{ml}$ of the same buffer and loaded into a Sephadex G-200 column $(1.5 \times 60 \mathrm{~cm})$ that equilibrated and eluted with $50 \mathrm{mM}$ phosphate buffer ( $\mathrm{pH} 7.0)$. Fractions of $2 \mathrm{ml}$ were collected at a flow rate of 10 $\mathrm{ml} /$ hour. The pooled and concentrated active xylanase fractions were loaded onto the Sephadex G-100 column $(1.5 \times 50 \mathrm{~cm})$ equilibrated and subsequently eluted by using the same buffer at a flow rate of 10 $\mathrm{ml} /$ hour. The resulting active fractions were pooled and used as the purified xylanase.

\section{Protein estimation}

During purification, protein was estimated by the method of bicinchoninic acid with bovine serum albumin (Sigma Co.) as a standard [25]. The protein content of eluants was measured by monitoring the optical density at $280 \mathrm{~nm}$.

\section{Molecular mass determination}

The molecular mass of the purified xylanase was estimated by SDS-PAGE electrophoresis (12\%) as described by Laemmli [26] using medium range molecular weight markers (14.4 to $97.4 \mathrm{kDa}$, Sigma). Proteins were visualized by staining with Coomassie Brilliant Blue R-250.

\section{Characterization of ESRAA-301097 xylanase}

The optimum temperature for xylanase activity was determined by measuring the activity at various temperatures $(25,30,35,40,45,50$, $55,60,65,70,75,80,85,90,95$ and $100^{\circ} \mathrm{C}$ ) and its thermal stability was estimated by incubating the enzyme at these different temperatures for $1 \mathrm{~h}$ and then the residual activity determined at the optimum assay temperature. Similarly, optimum $\mathrm{pH}$ for the purified enzyme was determined at optimized temperature using $0.1 \mathrm{M}$ buffers of different $\mathrm{pH}$ values such as citrate phosphate $(\mathrm{pH} 4.0-6.0)$, sodium phosphate ( $\mathrm{pH} 7.0$ ), Tris- $\mathrm{HCl}$ (pH 8.0-9.0), and glycine $\mathrm{NaOH}(\mathrm{pH} 10.0-11.0$ ) and its $\mathrm{pH}$ stability was determined by incubating the enzyme in the $\mathrm{pH}$ range $4-11$ for 24 hours at $30^{\circ} \mathrm{C}$ and then the residual activity was measured. The effect of different xylan concentrations $(1,2,3,4,5$ and $6 \%$ of birchwood xylan) as well as the substrate specificity of xylanase toward $1 \%$ of birchwood xylan, xylan oat splet, CM-cellulose and filter paper was evaluated. Moreover, the purified enzyme was incubated with $10 \mathrm{mM}$ of different salt solutions $\left(\mathrm{Mn}^{2+}, \mathrm{Cu}^{2+}, \mathrm{Mg}^{2+}, \mathrm{Zn}^{2+}, \mathrm{Fe}^{3+}, \mathrm{Na}^{+}, \mathrm{Ba}^{2+}\right.$, $\mathrm{Hg}^{+2}, \mathrm{Co}^{+2}, \mathrm{Cd}^{2+}, \mathrm{Pb}^{+2}, \mathrm{Ca}^{2+}, \mathrm{Ni}^{+}$and $\left.\mathrm{Li}^{+}\right), 1 \% \mathrm{v} / \mathrm{v}$ of different detergents (Triton X-100, sodium dodecyl sulphate, sodium tripolyphosphate, sodium tetraborate, Tween 20 and Tween 80 ), protease inhibitors, (phenyl methyl sulphonyl fluoride PMSF, iodoacetamide, 1,10-phenathroline, dithiotheitol DTT, p-chloromercuribenzoate PCMB, EDTA and EGTA at a concentration of 10 and $50 \mathrm{mM}$ as well as with different organic solvents (1-propanol, propyleacetate, benzene, toluene, n-hexane, decanol, isooctane, tetradecane, $n$-hexadecane and ethyl acetate, $50 \%(\mathrm{v} / \mathrm{v})$ for $1 \mathrm{~h}$ at $30^{\circ} \mathrm{C}$ and the residual activity of the purified xylanase of such chemical additive was determined and compared with the control (without inhibitors as 100\%).

\section{Results and Discussion}

\section{Isolation of endophytic Actinomycetes from different Egyptian medical plants}

Four of the most important Egyptian medical plants namely, Cympobogon proximus (halfabar) which used In Egyptian folk medicine as an effective renal antispasmodic, diuretic and antispasmodic agents [27], Artemisia judaica (shih balady) that used as antiseptic agent or tinctures applied for the relief of rheumatic pains [28]; Anethum graveolens (dill), which has antimicrobial, antihyperlipidaemic, antispasmodic, antihypercholesterolaemic activities [29] and Corchorus 
Citation: El-Gendy MMA, El-Bondkly AMA (2014) Optimization of Solid State Fermentation and Leaching Process Parameters for Improvement Xylanase Production by Endophytic Streptomyces sp. ESRAA-301097. J Microb Biochem Technol 6: 154-166. doi:10.4172/19485948.1000137

olitorius (malukhiyah) that exhibits several antifertility, anti-convulsive, antioxidants, anti-inflammatory, anti-proliferative, antimicrobial and antitumor activities with gastro-protective effect [30] were selected and tested for their endophytic actinobacteria. Cympobogon proximus hosted in its leaves; stems and roots 18, 11 and 24 endophytic isolates of actinobacteria among them 7, 4, and 10 isolates, respectively are xylanolytic strains (Table 1). Stems and roots of Artemisia judaica were colonized by 19 and 10 actinobacterial isolates out of them 7 and 3 isolates have xylanolytic activity. Interestingly, among the tested plants, Corchorus olitorius proved to be the best host for endophytic actinobacteria by noticing the growing number of derived isolates (29, 40 and 48 isolates) with the highest number of xylanolytic isolates (14, 16 and 21 isolates) from its leaves, stems and roots, respectively (Table 1). On the other hand, no actinobacteria were isolated from all organs of Anethum graveolens due to several endophytes can be isolated from different host but at the same time they are reported to be host specific [31]. Also whereas actinobacterial isolates were not derived from the leaves of Artemisia judaica, they were detected from its stems and roots due to many endophytes appear specialized to particular host tissues as reported previously by Suryanarayanan et al. [31]. Thus, such host specific/organ specific endophytes have been observed in the plants used in the present work. These data are sufficient for the Egyptian medical plants to be underexplored reservoirs of Actinomycetes especially those with xylanolytic activity.
The growth of microbes in the laboratory is dependent on the composition of the media and the cultivation conditions that are applied [32]. However maximum endophytic actinomycetes (86 isolates) were obtained in actinomycetes isolation agar medium followed by xylan agar medium (82 isolates) and minimum (31 isolates) detected in dextrose yeast extract malt extract agar (DYMA) (Table 1). Qin et al. [4] reported that high nutrient concentration medium (as in DYM) allowed fast growing bacteria to overgrow slower growing microorganisms but some media composed of amino acids as nitrogen sources (as in AIA) or cellulose and xylan as carbon sources (as in Xylan agar medium) had prominent isolation effectiveness for actinobacterial genera.

\section{Screening of the hyper xylanase producing actinomycete isolate}

Among 80 xylanolytic actinomycete isolates obtained in this study, 26; 33 and 21 isolates were detected as weak $(8-14 \mathrm{~mm})$; moderate (15-24 mm) and hyper xylanase producers $(25-35 \mathrm{~mm})$, respectively on xylan-agar plates. Further xylanase evaluation in xylan liquid medium supported endophytic actinomycete isolate ESRAA-301097 of Cympobogon proximus as the hyper xylanase producer. It displayed xylan digestion halo diameter of $35 \mathrm{~mm}$ in primary screening with enzyme activity equal to $52.06 \mathrm{Uml}^{-1}$ in secondary screening (Table 2), thus it was selected for further studies.

\begin{tabular}{|c|c|c|c|c|c|}
\hline Host plant name & Local name & Medicinal activities & Organ & Media used* & No. of derived Actinomycete isolate \\
\hline Cympobogon proximus & Halfa barr & $\begin{array}{l}\text { In Egyptian folk medicine as an effective renal } \\
\text { antispasmodic, diuretic and as antispasmodic } \\
\text { agent. }\end{array}$ & $\begin{array}{l}\text { Leaves } \\
\text { Stems } \\
\text { roots }\end{array}$ & $\begin{array}{l}\text { (AIA) } \\
\text { (DYM) } \\
(\text { XA) } \\
(\text { AIA) } \\
\text { (DYM) } \\
(\text { XA) } \\
(\text { AIA) } \\
\text { (DYM) } \\
(X A)\end{array}$ & $\begin{array}{l}8 \\
3 \\
7 \\
6 \\
1 \\
4 \\
10 \\
4 \\
10\end{array}$ \\
\hline Anethum graveolens & Dill & $\begin{array}{l}\text { antimicrobial, antihyperlipidaemic, antispasmodic, } \\
\text { antihypercholesterolaemic agent and for some } \\
\text { gastrointestinal ailments such as flatulence, } \\
\text { indigestion, stomachache and colic }\end{array}$ & $\begin{array}{l}\text { Leaves } \\
\text { Stems } \\
\text { Roots }\end{array}$ & $\begin{array}{l}\text { (AIA) } \\
\text { (DYM) } \\
\text { (XA) } \\
(\text { (AIA) } \\
\text { (DYM) } \\
(\text { XA) } \\
(\text { AIA) } \\
\text { (DYM) } \\
\text { (XA) }\end{array}$ & $\begin{array}{l}0 \\
0 \\
0 \\
0 \\
0 \\
0 \\
0 \\
0 \\
0\end{array}$ \\
\hline Artemisia judaica & Shih balady & $\begin{array}{l}\text { used as antiseptic agent or tinctures applied for } \\
\text { the relief of rheumatic pains }\end{array}$ & $\begin{array}{l}\text { Leaves } \\
\text { Stems } \\
\text { Roots }\end{array}$ & $\begin{array}{l}\text { (AIA) } \\
\text { (DYM) } \\
\text { (XA) } \\
(\text { (AIA) } \\
\text { (DYM) } \\
(\text { XA) } \\
\text { (AIA) } \\
\text { (DYM) } \\
\text { (XA) }\end{array}$ & $\begin{array}{l}0 \\
0 \\
0 \\
9 \\
3 \\
7 \\
5 \\
2 \\
3\end{array}$ \\
\hline Corchorus olitorius & Malukhiyah & $\begin{array}{l}\text { Exhibits several antifertility, anti-convulsive, } \\
\text { antioxidants, anti-inflammatory, anti-proliferative, } \\
\text { antimicrobial and antitumor activities with } \\
\text { gastroprotective effects }\end{array}$ & $\begin{array}{l}\text { Leaves } \\
\text { Stems } \\
\text { roots }\end{array}$ & $\begin{array}{l}\text { (AIA) } \\
\text { (DYM) } \\
\text { (XA) } \\
(\text { (AIA) } \\
\text { (DYM) } \\
(\text { XA) } \\
\text { (AIA) } \\
\text { (DYM) } \\
\text { (XA) }\end{array}$ & $\begin{array}{l}11 \\
4 \\
14 \\
16 \\
8 \\
16 \\
21 \\
6 \\
21\end{array}$ \\
\hline
\end{tabular}

*Actinomycetes isolation agar (AIA), dextrose yeast extract malt extract agar (DYM) and xylan agar (XA) media

Table 1: Medicinal plants selected for endophytic actinomycetes isolation using different cultivation media. 
Citation: El-Gendy MMA, El-Bondkly AMA (2014) Optimization of Solid State Fermentation and Leaching Process Parameters for Improvement Xylanase Production by Endophytic Streptomyces sp. ESRAA-301097. J Microb Biochem Technol 6: 154-166. doi:10.4172/19485948.1000137

\begin{tabular}{|l|c|c|}
\hline isolate & $\begin{array}{c}\text { Primary screening (diameter } \\
\text { of xylan digestion zone, } \mathbf{~ m m} \text { ) }\end{array}$ & $\begin{array}{c}\text { Secondary screening } \\
\text { (Uml-1) }\end{array}$ \\
\hline Esraa 300097 & 29 & 38.96 \\
Esraa 300197 & 34 & 45.08 \\
Esraa 300297 & 31 & 43.15 \\
Esraa 300397 & 30 & 42.21 \\
Esraa 300497 & 26 & 38.49 \\
Esraa 300597 & 25 & 31.57 \\
Esraa 300697 & 27 & 35.00 \\
Esraa 300797 & 30 & 40.12 \\
Esraa 300897 & 30 & 39.75 \\
Esraa 300997 & 34 & 45.04 \\
Esraa 301097 & 35 & 52.06 \\
Esraa 301197 & 26 & 34.73 \\
Esraa 301297 & 28 & 39.00 \\
Esraa 301397 & 27 & 33.98 \\
Esraa 301497 & 26 & 30.00 \\
Esraa 301597 & 33 & 40.19 \\
Esraa 301697 & 32 & 40.00 \\
Esraa 301797 & 35 & 45.90 \\
Esraa 301897 & 27 & 36.43 \\
Esraa 301997 & 30 & 40.18 \\
Esraa 302097 & 35 & 48.00 \\
\hline
\end{tabular}

Table 2: Xylanase activity $\left(\mathrm{Uml}^{-1}\right)$ of hyper xylanolytic endophytic actinobacteria after primary and secondary screening at $30^{\circ} \mathrm{C}$ for 5 days in selective xylan medium.

\section{Identification of the endophytic xylanolytic isolate ESRAA-301097}

The aerial mycelium of ESRAA-301097 strain formed spiral spore chains with spiny spore surface (Figure 1). It was developed well and ranged in color from reddish olive to dark gray but the substrate mycelium was ranged between deep red to dark brown (Table 3). As shown in Table 4 tests for diffusible pigments formation on ISP2; ISP3; ISP4 and ISP5, melanin formation, $\mathrm{H}_{2} \mathrm{~S}$ production, gelatin liquefaction, milk coagulation, milk peptonization and nitrate reduction are positive (Table 4). Chemotaxonomic analysis showed that the cell wall of the xylanolytic isolate, ESRAA-301097, contains LL-diaminopimelic acid in addition to lysine, glutamic acid and glycine but the whole-cell sugar analysis reveals the presence of the diagnostic sugars glucose, mannose, galactose and xylose (cell-wall type I) (Table 4). Whereas the phospholipid pattern of endophytic ESRAA-301097 isolate showed characteristic phospholipids of chemotype I that possess PE, DPG, PG, PIMS and PI, the major fatty acids components found are Iso- C14:0 (1.20\%), C14: 0 (0.52\%), AnteisoC15:0 (15.10\%), Iso- C15:0 (2.82\%), C15:0 (12.43\%), Iso- C16:0 (25.0\%), C16:0 (15.72\%), Anteiso-C16:0 (3.10\%), Anteiso-C17:0 (14.43\%), C17:0 (5.74\%), C18:0 (2.55\%), Iso-C18:0 (1.18\%) and C18:2 (0.21\%). Data in Table 4 refers to ESRAA-301097 quinone system of the predominant menaquinone MK-9(H6) (31\%); MK-9(H8) (24\%) followed by MK-10(H6) (22\%), moderate amounts of MK-10(H8) (10\%) and MK-9(H10) (8\%) beside minor amounts of MK-8(H8) (2\%); MK-10(H4) (2\%) and MK-10(H10) (1\%). The G+C content of ESRAA-301097 genomic DNA was determined to be $70.4 \%$ (Table 4). According to Kim et al. [33], the major menaquinones of the genus Streptomyces are MK-9(H6) and MK-9(H8), thus it was interesting that strain ESRAA-301097 contained in addition to MK-9(H6) and MK-9(H8) unusual quinone systems. Data in Table 4 showed that all carbon and nitrogen sources tested with the exception of rhamnose, sorbitol and inositol are utilized by ESRAA-301097. Moreover, it has degradable activity towards chitin, aesculin, citric acid, succinic acid, malonic acid, pectin, malic acid, starch, cellulose, inulin, xylan and gelatin. On the other hand, ESRAA-301097 showed resistance against clindamycin, furazolidone, amikacin, penicillin G, kanamycin, furazolidone, streptomycin, erythromycin, cefazolin and rocephin but it was sensitive to gentamycin, tetracycline, lincomycin, vancomycin, chloromycetin, rifampicin and tobramycin (Table 4). Furthermore, ESRAA-301097 strain was grow well in $\mathrm{pH}$ range 4-11 and temperature range $15-45^{\circ} \mathrm{C}$ and $\mathrm{NaCl}$ up to $18 \%$.

\section{Molecular identification of hyper-xylanase producing strain ESRAA-301097 through 16S rRNA gene sequencing}

The 16S rDNA region of the producing strain (ESRAA-301097) was amplified, sequenced, and submitted to GenBank (Accession no. KF877333). The obtained sequences were compared with those in the National Center for Biotechnology Information (NCBI) Nucleotide Sequence Database by using the Basic Local Alignment Search Tool (BLAST) algorithm. A comparative analysis by MEGA6 and ClustalW software demonstrated that $16 \mathrm{~S}$ rDNA sequence from hyperxylanase producing strain ESRAA-301097 had a significant identity to a number of Streptomyces sp. The comparison of xylanolytic strain ESRAA-301097 with sequences of the reference species of bacteria contained in genomic database banks exhibited a similarity of 100 , 100, 100 and $99 \%$ with S. variabilis NRRL B-3984, S. vinaceus NBRC 3406, S. griseoincarnatus NBRC 12871 and S. labedae, respectively. The phylogenetic tree obtained by applying the neighbor joining method is illustrated in Figure 2. According to the analysis of $16 \mathrm{~S}$ rDNA sequence, together with their morphological and biochemical characteristics, hyper-xylanase producing strain ESRAA-301097 was identified as Streptomyces sp. and designated as Streptomyces sp. ESRAA-301097. Manfio et al. [34] and El-Bondkly et al. [24] reported that the (a)

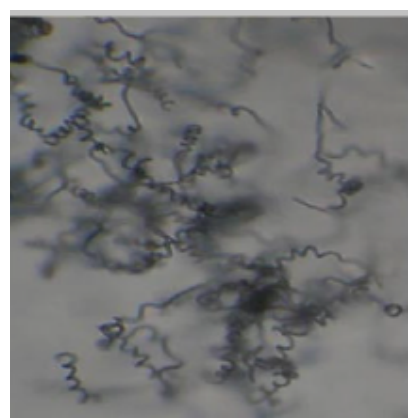

(b)

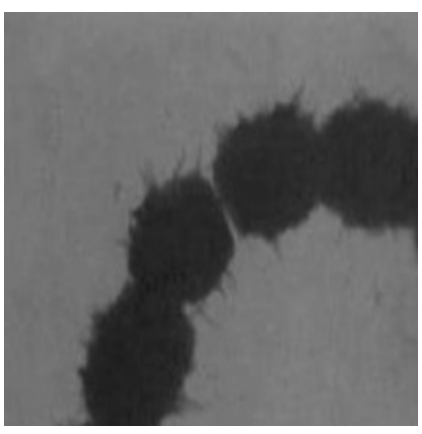

Figure 1: Scanning electron micrographs of endophytic hyper xylanolytic producer strain ESRAA-301097: (a) Spiral spore chains; (b) spiny spore surface ornamentation.

\begin{tabular}{|c|c|c|c|c|}
\hline Medium* & Growth & Sporulation & $\begin{array}{c}\text { Aerial } \\
\text { mycelium }\end{array}$ & $\begin{array}{l}\text { Substrate } \\
\text { mycelium }\end{array}$ \\
\hline $\begin{array}{c}\text { ISP } 2 \\
\text { ISP } 3 \\
\text { ISP } 4 \\
\text { ISP } 5 \\
\text { ISP } 7 \\
\text { Czapek's agar } \\
\text { Starch casein agar } \\
\text { Bennett's agar } \\
\text { Hickey \&Tresner agar } \\
\text { Nutrient agar }\end{array}$ & $\begin{array}{l}\text { Abundant } \\
\text { Good } \\
\text { Abundant } \\
\text { Abundant } \\
\text { Good } \\
\text { Moderate } \\
\text { Abundant } \\
\text { Good } \\
\text { Good } \\
\text { Poor }\end{array}$ & $\begin{array}{l}\text { Good } \\
\text { Good } \\
\text { Good } \\
\text { Good } \\
\text { Good } \\
\text { Poor } \\
\text { Good } \\
\text { Good } \\
\text { Good } \\
\text { Poor }\end{array}$ & $\begin{array}{c}\text { Gray } \\
\text { Dark gray } \\
\text { Reddish olive } \\
\text { Whitish gray } \\
\text { Dark gray } \\
\text { Light gray } \\
\text { Gray } \\
\text { Whitish gray } \\
\text { Gray } \\
\text { Gray }\end{array}$ & $\begin{array}{l}\text { Dark brown } \\
\text { Reddish brown } \\
\text { Brown } \\
\text { Grayish brown } \\
\text { Grayish brown } \\
\text { Brownish red } \\
\text { Brownish red } \\
\text { Light brown } \\
\text { Deep red } \\
\text { Brown }\end{array}$ \\
\hline
\end{tabular}

*ISP 2, yeast extract agar; ISP 3, oat meal agar; ISP 4, inorganic salt starch agar ISP 5, glycerol asparagines agar and ISP 7, tyrosine agar

Table 3: Phenotypic characteristics of the hyper xylanolytic producer strain ESRAA-301097. 
Citation: El-Gendy MMA, El-Bondkly AMA (2014) Optimization of Solid State Fermentation and Leaching Process Parameters for Improvement Xylanase Production by Endophytic Streptomyces sp. ESRAA-301097. J Microb Biochem Technol 6: 154-166. doi:10.4172/19485948.1000137

\begin{tabular}{|c|c|c|c|}
\hline \multicolumn{4}{|c|}{ Chemotypic characters of the hyper xylanolytic producer strain Esraa 301097} \\
\hline Spore surface & Spiny & Inulin & + \\
\hline Spore chain morphology & straight & Xylan & + \\
\hline Spores / chain & $>10$ & Gelatine & + \\
\hline Melanin production & + & Carbon utilization (1\%) & \\
\hline $\mathrm{H} 2 \mathrm{~S}$ production & + & D- Glucose & + \\
\hline Soluble pigment on & & D-Ribose & + \\
\hline ISP 2 & + & L-Arabinose & + \\
\hline ISP 3 & + & Fucose & + \\
\hline ISP 4 & + & D- xylose & + \\
\hline ISP 5 & + & Rhamnose & - \\
\hline Milk coagulation & + & D-Mannitol & + \\
\hline Milk peptonization & + & Adonitol & + \\
\hline $\mathrm{NaNO}_{3}$ reduction & + & Glycerol & + \\
\hline Cell wall amino acids & L, L-diaminopimelic acid, lysine, glutamic acid, glycine & Sorbitol & - \\
\hline Whole cell sugars & Glucose, mannose, galactose, xylose & Lactose & + \\
\hline Major fatty acids (\%) & & sucrose & + \\
\hline Iso- C14:0 & 1. 20 & Maltose & + \\
\hline C14:0 & 0.52 & Fructose & + \\
\hline Anteiso- C15:0 & 15.10 & D-mannose & + \\
\hline Iso- C15:0 & 2.82 & Raffinose & + \\
\hline C15:0 & 12.43 & L-Inositol & - \\
\hline Iso- C16:0 & 25.0 & Nitrogen source utilization & \\
\hline C16:0 & 15.72 & Casein & + \\
\hline Anteiso-C16:0 & 3.10 & L-Histidine & + \\
\hline Anteiso-C17:0 & 14.43 & L-phenylalanine & + \\
\hline C17:0 & 5.74 & DI-Methionine & + \\
\hline C18:0 & 2.55 & L-Serine & + \\
\hline Iso-C18:0 & 1.18 & L-Valine & + \\
\hline C18:2 & 0.21 & Urea & + \\
\hline Characteristic phospholipids & PE, DPG, PG, PIMS and PI & Response to antibiotics & \\
\hline Major menaquinones & & Clindamycin (2 mg/disc) & $\mathrm{R}$ \\
\hline MK-8(H8) & $2 \%$ & Furazolidone (15 mg/disc) & $\mathrm{R}$ \\
\hline MK-9 (H6) & $31 \%$ & Gentamycin (10 mg/disc) & $\mathrm{S}$ \\
\hline MK-9(H8) & $24 \%$ & Amikacin (30 mg/disc) & $\mathrm{R}$ \\
\hline MK-9(H10) & $8 \%$ & Penicillin G (10 mg/disc) & $\mathrm{R}$ \\
\hline MK-10(H4) & $2 \%$ & Kanamycin (30 mg/disc) & $\mathrm{R}$ \\
\hline MK-10(H6) & $22 \%$ & Furazolidone (15 mg/disc) & $\mathrm{R}$ \\
\hline MK-10(H8) & $10 \%$ & Tetracycline (30 mg/disc) & $S$ \\
\hline MK-10(H10) & $1 \%$ & Lincomycin (2 mg/disc) & S \\
\hline Hydrolysis activity (0.1\%) & & Streptomycin (10 mg/disc) & $\mathrm{R}$ \\
\hline Chitin & + & Vancomycin (30 mg/disc) & $\mathrm{S}$ \\
\hline Aesculin & + & Chloromycetin (30 mg/disc) & $S$ \\
\hline Citric acid & + & Erythromycin (15 mg/disc) & $\mathrm{R}$ \\
\hline Succinic acid & + & Cefazolin (30 mg/disc) & $\mathrm{R}$ \\
\hline Malonic acid & - & Rocephin (30 mg/disc) & $\mathrm{R}$ \\
\hline Pectin & + & Rifampicin (5 mg/disc) & $S$ \\
\hline Fumaric acid & - & Tobramycin (10 mg/disc) & S \\
\hline Malic acid & + & $\mathrm{pH}$ range for growth & $4-11$ \\
\hline Starch & + & Temp. range for growth $\left({ }^{\circ} \mathrm{C}\right)$ & $15-45$ \\
\hline Cellulose & + & $\mathrm{NaCl}$ tolerance $(\%)$ & Up to $18 \%$ \\
\hline & & DNA G+C content $(\mathrm{mol} \%)$ & 70.4 \\
\hline
\end{tabular}

PE, phosphatidylethanolamine; DPG, diphosphatidylglycerol; PG, phosphatidylglycerol; PI, phosphatidylinositol; PIMS, phosphatidylinositolmannosides; +, utilized or reaction positive; -, not utilized or reaction negative, $\mathrm{R}$, resist; $\mathrm{S}$, sensitive

Table 4: Chemotypic characteristics of the hyper xylanolytic producer strain ESRAA-301097.

description of Streptomyces species must be based on a combination of genotypic and phenotypic data and if sufficient evidence is provided that an unknown is clearly different in both genotypic and phenotypic features, novel species can be described.

\section{Xylanase production in submerged fermentation}

As shown in Table 5 wheat bran; corncob and sugarcane bagasse resulted in $33.19,46.12$ and $47.30 \mathrm{Uml}^{-1}$ of xylanase at the 5 th, 5th and 6th day of fermentation by Streptomyces sp. ESRAA-301097, respectively and then gradually declined. The reduction in xylanase yield after optimum period was probably due to the depletion of available nutrient or due to proteolysis [2]. When Data in Table 5 compared with those in Figures 3 and 4, it is obviously indicated to SSF as an attractive tool for the production of xylanase over submerged fermentation due to higher productivity. Previously, xylanase production was achieved by Streptomyces species in different technique but SSF presents some advantages over SmF concerning it is a fit technique for using natural substrates (agro-industrial residues) as nutritional support [3,10,35].

\section{Optimization of solid state fermentation (SSF) process parameters}

Substrate support (agro-industrial residues) versus incubation time:

There is an intense focus on the valorization of agro-industrial residues for production of value added products. Data in Figure 3 indicating that all agro industrial residues used in this study could function only as nutrient support as well as inducer for xylanase production by Streptomyces sp. ESRAA-301097 in the range from 370 to $1404 \mathrm{Ugds}^{-1}$ (with banana stalk and corncob, respectively). Moreover, data in Figure 4 indicating the role of inducers for effective induction of xylanase, xylan containing substrate such as corn cob 
Citation: El-Gendy MMA, El-Bondkly AMA (2014) Optimization of Solid State Fermentation and Leaching Process Parameters for Improvement Xylanase Production by Endophytic Streptomyces sp. ESRAA-301097. J Microb Biochem Technol 6: 154-166. doi:10.4172/19485948.1000137

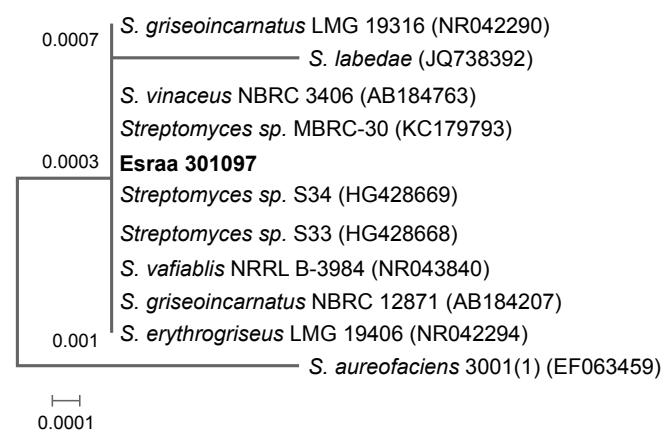

Figure 2: Phylogenetic relation of endophytic marine Streptomyces $\mathrm{sp}$ ESRAA-301097 strain sequence with 16S rDNA of the highest similar bacteria. The dendogram was generated by the neighbor-joining method using MEGA6 software.

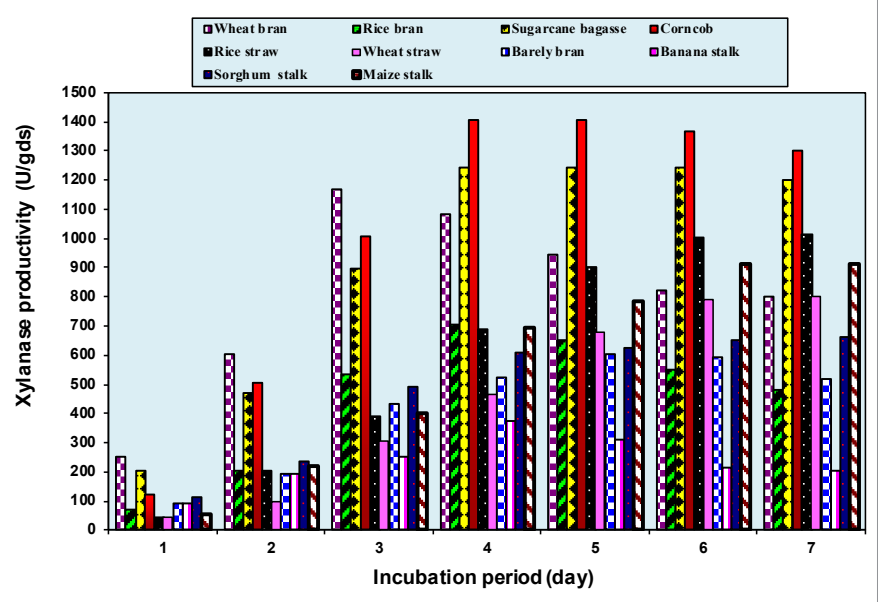

Figure 3: Screening and optimization of solid agro residue substrates for ESRAA-301097 xylanase production $\left(\mathrm{Ugds}^{-1}\right)$ in SSF at different incubation periods.

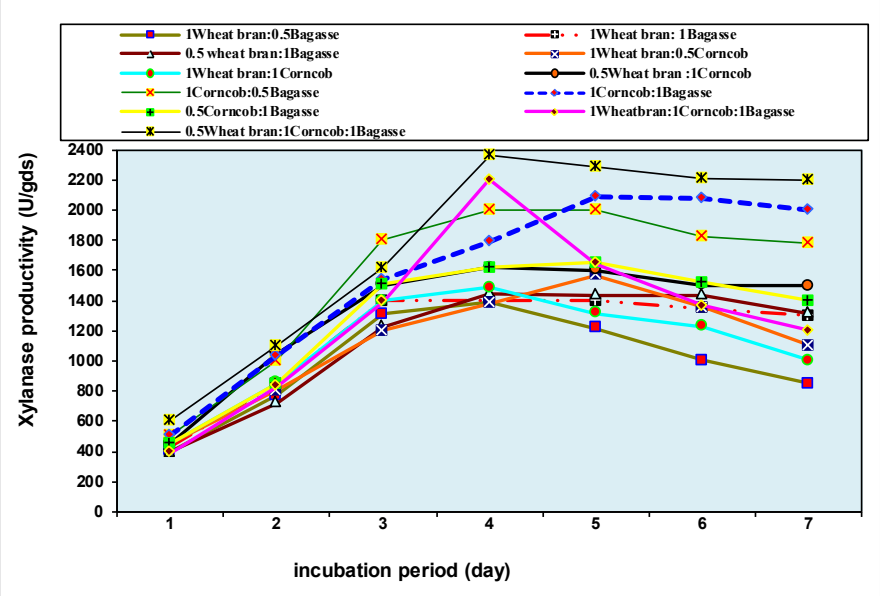

Figure 4: Effect of different combinations at different concentrations of agro residues for hyper production of ESRAA-301097 xylanase $\left(\right.$ Ugds $\left.^{-1}\right)$ in SSF at different incubation periods.

(23\% xylose and $28 \%$ xylan) and sugarcane bagasse (28-30\% xylan) gave the highest level of xylanase production (1404 and $1241 \mathrm{Ugds}^{-1}$ ) after the 4 th day of fermentation and then declined till day 7 reaching
1299 and $1200 \mathrm{Ugds}^{-1}$, respectively. However, Li et al. [36] reported that corncobs xylan supported the highest xylanase activity to 334.34 $\mathrm{U} / \mathrm{ml}$ after 7 days of cultivation in S. chartreusis L1105, Ninawe and Kuhad [3] reported wheat bran and corn cob as an enhancer for xylanase production by Streptomyces cyancus SN32, Techapun et al. [37] supported cane bagasse as inducer for cellulase-free xylanase from Streptomyces sp. Ab106 and a significant amounts of xylanase were produced by Aspergillus fumigatus on a variety of agro-wastes but wheat bran supported higher xylanase production followed by rice bran, rice straw and corn cobs as the sole carbon source $(8,450 ; 5,500$; 4,600 and $4,500 \mathrm{U} / \mathrm{L}$, respectively) [2]. It was previously reported that in xylanase production corncobs act as efficient inducer due to its high content of xylan, [36] sugarcane bagasse verified due to its high water retention capacity [10] but wheat bran as a rather complete nutrient (18\% protein, $5 \%$ fat and $62 \%$ carbohydrate) enhance growth and xylanase production [2]. Thus when corncob mixed with sugarcane bagasse and wheat bran at a ratio of 0.5: 1.0: 1.0 in SSF, the highest xylanase production (2364 $\mathrm{Ugds}^{-1}$ ) was achieved (Figure 4). This study highlighted that developing a xylanase production process based upon mixture of CC, SCB and WB as a technical substrate is very attractive as they are cheap and readily available sources of carbon.

\section{Incubation temperature}

As shown in Table 6, maximum xylanase activity (3112.19 Ugds $\left.{ }^{1}\right)$ was attained at $30-40^{\circ} \mathrm{C}$. Streptomycetes generally are mesophilic in nature with a growth temperature range of $15-45^{\circ} \mathrm{C}$, then very low temperature may not trigger the metabolism of the organism while very high temperature (over $45^{\circ} \mathrm{C}$ ) results in the denaturation of the metabolic enzymes. This optimal temperature is similar to those described for $S$. chartreusis $\mathrm{L} 1105\left(40^{\circ} \mathrm{C}\right)[36]$ but quite different from Streptomyces sp. Ab106 xylanase $\left(55^{\circ} \mathrm{C}\right)$ [37].

Initial $\mathbf{p H}$ : The effect of initial $\mathrm{pH}$ values on xylanase production is shown in Table 6. When initial pH was equal to 3.0, no xylanolytic activity was detected. Xylanase productivity gradually increased with increasing $\mathrm{pH}$ reaching an optimum level at $\mathrm{pH} 7.0$ (3112.00 $\left.\mathrm{Ugds}^{-1}\right)$ and thereafter decreased at higher values reaching $1005.45 \mathrm{Ugds}^{-1}$ at $\mathrm{pH}$ 10.0. Our findings agree well with earlier studies that showed that xylanase production is markedly dependent on $\mathrm{pH}$ due to it influences the enzymatic systems and its transport across the cell membrane [36]. Previous studies indicated neutral $\mathrm{pH}$ values between 6.0 and 7.0 for optimal xylanase production by other Streptomyces strains as Streptomyces sp. 594 and S. chartreusis L1105 [36].

\section{Inoculum level}

The amount of Streptomyces sp. ESRAA-301097 inoculum added to the fermentation medium has significant effect on xylanase production under SSF. Optimum enzyme productivity (3370.52 Ugds $^{-1}$ ) was obtained with an inoculum level of $1 \times 10^{7}$ spore $\mathrm{gds}^{-1}$. Higher or lower inoculum level decreased xylanase production to 701.40 and 1750.19 $\mathrm{Ugds}^{-1}$ at inoculums concentration $10^{3}$ and $10^{10}$ spore gds ${ }^{-1}$, respectively (Table 6). Lower inoculum density than optimum level may not be sufficient for producing the require biomass while higher inoculum can cause fierce competition for nutrients [8]. Our data are similar to those obtained by Alberton et al. [10] for maximum xylanase production by Streptomyces viridosporus T7.

\section{Initial moisture content (IMC)}

Initial moisture level of the substrate acts as a fundamental controlling parameter for enzyme production in SSF. The highest 
Citation: El-Gendy MMA, El-Bondkly AMA (2014) Optimization of Solid State Fermentation and Leaching Process Parameters for Improvement Xylanase Production by Endophytic Streptomyces sp. ESRAA-301097. J Microb Biochem Technol 6: 154-166. doi:10.4172/19485948.1000137

\begin{tabular}{|c|c|c|c|c|c|c|c|}
\hline \multirow{2}{*}{ Agro industrial residues } & \multicolumn{7}{|c|}{ Xylanase production $\left(\mathrm{Uml}^{-1}\right)$ during different fermentation period (day) } \\
\hline & 1 & 2 & 3 & 4 & 5 & 6 & 7 \\
\hline Wheat bran (WB) & 10.16 & 15.94 & 23.70 & 28.72 & 33.19 & 20.12 & 16.00 \\
\hline Rice bran (RB) & 8.90 & 13.32 & 18.05 & 19.78 & 20.31 & 20.00 & 18.64 \\
\hline Sugarcane bagasse (SCB) & 16.42 & 29.00 & 30.93 & 31.33 & 40.30 & 47.30 & 40.30 \\
\hline Corncob (CC) & 9.06 & 17.16 & 24.20 & 32.16 & 46.12 & 40.53 & 40.51 \\
\hline Rice straw (RS) & 2.80 & 7.52 & 11.43 & 15.80 & 18.02 & 15.65 & 14.00 \\
\hline Wheat straw (WS) & 3.17 & 9.00 & 11.68 & 16.02 & 19.35 & 19.35 & 19.00 \\
\hline Barely bran (BB) & 5.30 & 6.91 & 12.26 & 16.00 & 16.00 & 14.50 & 11.62 \\
\hline Banana stalk (BS) & 1.00 & 1.84 & 4.00 & 7.39 & 8.50 & 11.14 & 9.54 \\
\hline Sorghum stalk (SS) & 2.25 & 3.90 & 5.16 & 8.06 & 10.04 & 13.90 & 11.00 \\
\hline Maize stalk (MS) & 4.10 & 8.30 & 13.99 & 20.31 & 22.18 & 21.40 & 21.00 \\
\hline
\end{tabular}

Table 5: Impact of different agro-industrial residues under SMF on ESRAA-301097 xylanase production (Uml-1) over different incubation periods.

\begin{tabular}{|c|c|c|c|}
\hline Process parameter & Xylanase production $\left(\right.$ Ugds $\left.^{-1}\right)$ & Process parameter & Xylanase production (Ugds $\left.{ }^{-1}\right)$ \\
\hline 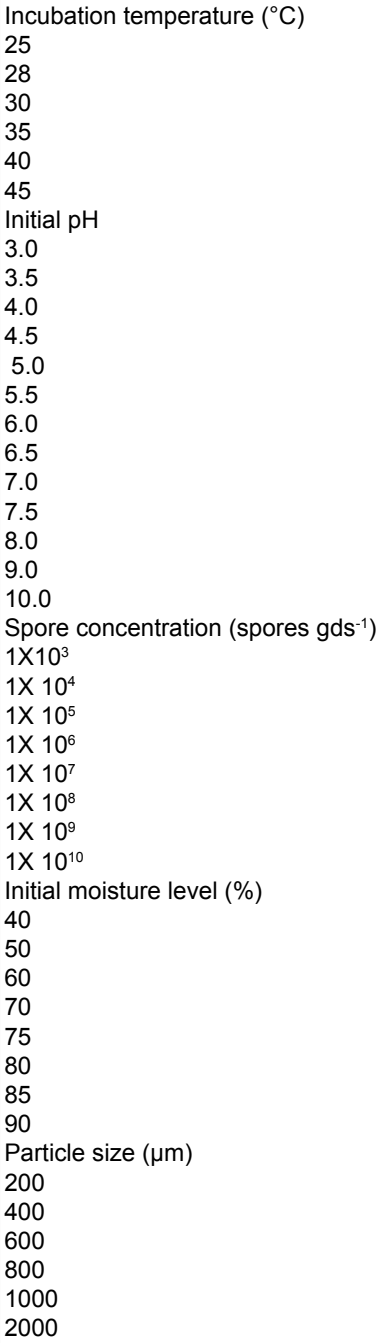 & $\begin{array}{l}2000.41 \\
2365.00 \\
3112.19 \\
3112.19 \\
3112.19 \\
2600.54 \\
\\
0.0 \\
100.28 \\
304.76 \\
700.11 \\
1280.24 \\
1900.04 \\
2212.65 \\
2609.31 \\
3112.00 \\
2819.30 \\
2750.74 \\
1907.00 \\
1005.45 \\
\\
701.40 \\
1100.17 \\
1930.29 \\
3112.18 \\
3370.52 \\
2915.84 \\
2180.16 \\
1750.19 \\
1041.79 \\
1960.00 \\
2803.17 \\
3372.58 \\
3410.41 \\
3650.50 \\
3650.50 \\
3407.19 \\
1209.20 \\
2300.08 \\
3650.29 \\
3819.00 \\
3043.59 \\
2218.13\end{array}$ & 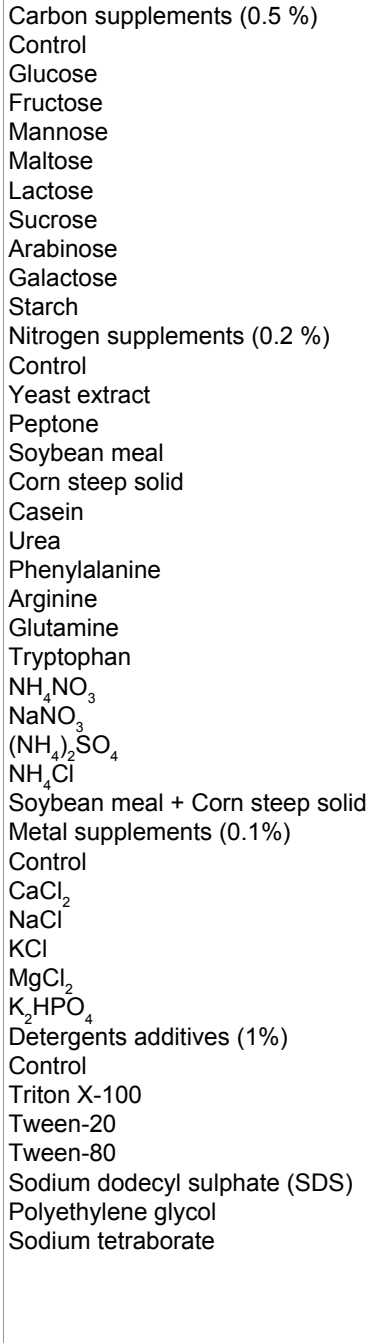 & $\begin{array}{l}3819.00 \\
600.16 \\
1032.82 \\
2160.27 \\
1019.50 \\
1618.04 \\
1204.35 \\
1032.82 \\
1322.50 \\
2002.25 \\
\\
3819.00 \\
3422.00 \\
3068.00 \\
4500.39 \\
4385.40 \\
3270.10 \\
2477.18 \\
2301.00 \\
3290.75 \\
2000.08 \\
4029.40 \\
2989.26 \\
3999.07 \\
2149.37 \\
2594.22 \\
4734.03 \\
\\
4734.03 \\
4604.40 \\
4175.62 \\
4182.02 \\
4214.00 \\
4673.55 \\
4734.03 \\
5150.18 \\
5709.20 \\
5294.00 \\
750.29 \\
5000.10 \\
1804.70\end{array}$ \\
\hline
\end{tabular}

Table 6: Optimization of SSF physical and nutritional process parameters of xylanase production by Streptomyces sp. ESRAA-301097.

enzyme production $\left(3650.50 \mathrm{Ugds}^{-1}\right)$ was obtained at $80-85 \%$ initial moisture content and then xylanase activity was decreased with higher or lower initial moisture content (Table 6). Whereas increase in SSF moisture content reduce the porosity of solid particles thus limiting oxygen transfer, a decrease in moisture content reduce the solubility and swelling of solid substrate with higher water tension [8]. Ideal moisture content for xylanase production from $S$. viridosporus T7A and S. chartreusis L1115 was over $90 \%$ but $75 \%$ elucidated xylanase yield from Streptomyces sp. QG-11-3 to $2360 \mathrm{Ugds}^{-1}[10,36,38]$.

\section{Substrate particle size}

Particle size of solid substrate and therefore the specific surface area was found to be one among the crucial factors affecting xylanase production by endophytic Streptomyces sp. ESRAA-301097 (Table 6). Maximum xylanase productivity (3819.00 $\mathrm{Ugds}^{-1}$ ) was obtained from $800 \mu \mathrm{m}$ sized particles and less enzyme detected with bigger or smaller particles. These results are in line with that obtained for particle size of sorghum straw for xylanase production by Thermomyces lanuginosus under SSF [35]. Lesser enzyme titer obtained on sized particles below 
Citation: El-Gendy MMA, El-Bondkly AMA (2014) Optimization of Solid State Fermentation and Leaching Process Parameters for Improvement Xylanase Production by Endophytic Streptomyces sp. ESRAA-301097. J Microb Biochem Technol 6: 154-166. doi:10.4172/19485948.1000137

$800 \mu \mathrm{m}$ may be attributed to increasing mycelia thickness around the substrate particles with decreasing porosity of the substrate bed and then Streptomyces sp. ESRAA-301097 mycelium could not penetrate deep into the particles but with larger particle sizes, the saturated surface area for growth is less and productivity correspondingly less [8]. Mixture of substrate support with $800 \mu \mathrm{m}$ particle size possibly provided sufficient surface area and aeration to actinobacteria for growth resulting in increased xylanase production.

\section{Carbon supplementations}

In the present study, the supported mixture $(\mathrm{CC}+\mathrm{SCB}+\mathrm{WB})$ was able to function only as nutrient and inducer for xylanase production by Streptomyces sp. ESRAA-301097 without needing any carbon supplementation (Table 6). In comparison with the control (3819.00 $\left.\mathrm{Ugds}^{-1}\right)$, the highest reduction $\left(600.16 \mathrm{Ugds}^{-1}\right)$ was obtained with glucose. This decrease may be attributed to xylanase synthesis repressed when easily metabolizable carbon sources present, suggesting that enzyme synthesis is controlled by a transitory regulatory status and catabolic repression [10]. Conversely, the highest level of S. lividans xylanase production was detected in wheat straw supplemented with $2 \%$ glucose [39].

\section{Nitrogen supplementations}

The mechanisms that govern the formation of enzymes are influenced by the availability and type of nitrogenous precursors for protein synthesis. Adding of soybean meal, corn steep solid and $\mathrm{NaNO}_{3}$ enhanced xylanase productivity to $17.842,14.831$ and 4.715 $\%$, respectively (Table 6 ). Moreover, using a mixture of soybean and corn steep solid as nitrogen source resulted in $23.96 \%$ increase in xylanase production by Streptomyces sp. ESRAA-301097. Conversely, with the exception of tryptophan (4029.40 $\left.\mathrm{Ugds}^{-1}\right)$ there was significant decrease in enzyme yield with amino acids and ammonium salts supplementations. Nitrogen source can significantly affect the $\mathrm{pH}$ of the medium during the course of fermentation which in turn may influence enzyme activity and stability. Soybean meal is complex and conditioned nitrogen source that does not cause catabolite repression and probably contains approximately all kinds of amino acids [2] which can be readily absorbed by Streptomyces sp. ESRAA-301097 mycelium. Similar to our results, soybean meal was observed to be the best nitrogen source for xylanase production by alkalophilic Streptomyces species CD3 [40] and Aspergillus fumigates [2].

\section{Metal supplementations}

No enhancement in xylanase production was occurred when Streptomyces sp. ESRAA-301097 was grown on metal salts source (Table 6), thus the salt requirements for the production of this particular enzyme was apparently provided by the solid substrates (CC, SCB, WB, SB and CSS) used in SSF. These finding are important in terms of the cost of xylanase production process [8]. In contrast, Abd El-Nasser et al. [39] reported that, some divalent metal salts supplemented to wheat straw as agriculture byproduct stimulated xylanase enzyme formation by Streptomyces lividans.

\section{Detergents additives}

Detergent effects on xylanase production by Streptomyces sp. ESRAA-301097 were varied. Tween-20; Tween-80; Triton X-100 and polyethylene glycol increased xylanolytic productivity to 5709.20; 5294.00; 5150.18 and $5000.10 \mathrm{Ugds}^{-1}$, respectively but the addition of the ionic surfactants sodium dodecyl sulphate (SDS) to the fermentation medium resulted in a severe reduction in enzyme yield

\begin{tabular}{|c|c|c|c|}
\hline Leaching parameter & Xylanase activity (Ugds ${ }^{-1}$ ) & Leaching parameter & Xylanase activity $\left(\right.$ Ugds $\left.^{-1}\right)$ \\
\hline Leaching agents $(1: 10, w / v)$ & & Soaking time (min) & \\
\hline $\mathrm{H}_{2} \mathrm{O}$ & 2670.81 & 60 & 3305.21 \\
\hline Methanol & 2150.16 & 90 & 4890.40 \\
\hline Acetone & 2218.43 & 120 & 6290.10 \\
\hline Butanol & 3500.80 & 150 & 5970.12 \\
\hline Glycerol & 3902.24 & 180 & 4600.59 \\
\hline $\mathrm{NaCl}(1.0 \%)$ & 5000.29 & $\mathrm{pH}$ of extraction process & \\
\hline Citrate buffer $(\mathrm{pH} 4.0,0.1 \mathrm{M})$ & 5708.51 & 3 & 5734.40 \\
\hline Citrate buffer (pH 6.0, $0.1 \mathrm{M})$ & 5295.90 & 4 & 6290.10 \\
\hline Phosphate buffer ( $\mathrm{pH} 7.0,0.1 \mathrm{M})$ & 3366.70 & 5 & 5585.90 \\
\hline Glycine-NaOH buffer ( $\mathrm{pH} 10.0,0.1 \mathrm{M})$ & 560.84 & 6 & 4431.90 \\
\hline Tween $80(0.1 \%)$ & 5720.00 & 7 & 1600.30 \\
\hline Tween $80(0.2 \%)$ & 5812.04 & 8 & 1170.28 \\
\hline Tween $80(0.3 \%)$ & 5769.28 & 9 & 1054.22 \\
\hline Citrate buffer $(\mathrm{pH} 4.0,0.1 \mathrm{M})+$ Tween $80(0.2 \%)$ & 6290.10 & 10 & 754.22 \\
\hline Leaching agent: fermented substrate ratio $(\mathrm{w} / \mathrm{v})$ & & Temperature of extraction process $\left({ }^{\circ} \mathrm{C}\right)$ & \\
\hline $1: 2$ & 1002.33 & 30 & 2216.65 \\
\hline $1: 4$ & 1930.16 & 40 & 4372.10 \\
\hline $1: 6$ & 4893.10 & 45 & 6290.10 \\
\hline $1: 8$ & 6290.10 & 50 & 6312.45 \\
\hline $1: 10$ & 6290.10 & 55 & 5396.00 \\
\hline $1: 12$ & 6034.24 & 60 & 4153.07 \\
\hline $1: 20$ & 5481.00 & 70 & 3305.19 \\
\hline Soaking time & & Agitation mode (150 rpm) & 6312.45 \\
\hline 30 & 2196. 74 & Static mode & 3103.72 \\
\hline
\end{tabular}

Table 7: Optimization of extraction process parameters of ESRAA-301097 xylanase $\left(\mathrm{Ugds}^{-1}\right)$.

\begin{tabular}{|c|c|c|c|c|c|}
\hline Purification step & Total protein $(\mathrm{mg})$ & Xylanase activity (U) & Specific activity (U/mg) & Yield (\%) & Purification fold \\
\hline $\begin{array}{l}\text { Crude extract } \\
\left(\mathrm{NH}_{4}\right) 2 \mathrm{SO}_{4} \text { fractionation }(60-80 \%) \\
\text { DEAE- cellulose chromatography } \\
\text { Sephadex G-200 chromatography } \\
\text { Sephadex G-100 chromatography }\end{array}$ & $\begin{array}{l}1986.50 \\
671.00 \\
151.11 \\
23.62 \\
14.48\end{array}$ & $\begin{array}{l}21975.00 \\
17395.42 \\
11736.86 \\
9088.65 \\
7145.53\end{array}$ & $\begin{array}{l}11.06 \\
25.93 \\
77.67 \\
384.79 \\
493.48\end{array}$ & $\begin{array}{l}100 \\
79.16 \\
53.41 \\
41.36 \\
32.52\end{array}$ & $\begin{array}{l}1 \\
2.344 \\
7.021 \\
34.784 \\
44.610\end{array}$ \\
\hline
\end{tabular}

Table 8: Purification profile of xylanase isolated from Streptomyces sp. ESRAA -301097 after growing in SSF. 
Citation: El-Gendy MMA, El-Bondkly AMA (2014) Optimization of Solid State Fermentation and Leaching Process Parameters for Improvement Xylanase Production by Endophytic Streptomyces sp. ESRAA-301097. J Microb Biochem Technol 6: 154-166. doi:10.4172/19485948.1000137

to $750.29 \mathrm{Ugds}^{-1}$ (Table 6). Whereas stimulatory effect of Tween 20 on xylanase production could be attributed to its effect on cell membrane permeability or by disrupting nonspecific binding of enzymes to substrates and thus exertion a positive effect on desorption and recycling of xylanase, the severe reduction in enzyme yield by SDS might be due to conformational changes in the tertiary secondary structure of the protein, binding of surfactants to the active site of the enzyme or by changing the substrate nature through decreasing the availability of reaction sites. Previously xylanase production by alkalophilic Streptomyces species and Streptomyces chartreusis L1105 was greatly enhanced when the medium supplemented with Tween 80 $[36,40,41]$

\section{Optimization of leaching process parameters for Streptomyces sp. ESRAA-301097 xylanase}

Recovery of the enzyme from the fermented matter is an important factor that affects the cost-effectiveness of the overall process. Among various leaching agents, the highest enzyme yield (6290.10 $\left.\mathrm{Ugds}^{-1}\right)$ was leached from the fermented matter by citrate buffer $(0.1 \mathrm{M}, \mathrm{pH}$ 4.0) containing $0.2 \%$ Tween 80 (Table 7). By increasing the ratio of leaching agent from 1:2 to 1:8 - 1:10 (w/v), the efficiency of leaching process was increased 6.276-fold (Table 7). Furthermore, the yield of leached enzyme was increased 2.863-fold when contact time was extended from 30 to $120 \mathrm{~min}$. Moreover, data in Table 7 indicated that the quantum of xylanase recovery from the fermented mixture $(\mathrm{CC}+\mathrm{SCB}+\mathrm{WB}+\mathrm{SB}+\mathrm{CSS})$ at leaching $\mathrm{pH} 4.0$, leaching temperature of $50^{\circ} \mathrm{C}$ and under agitation mode $(150 \mathrm{rpm})$ increased to $6312.45 \mathrm{Ugds}^{-1}$.

\section{Purification of ESRAA-301097 xylanase}

The elution profile of ESRAA-301097 Xylanase on DEAE-cellulose chromatography showed only one pool of xylanase activity indicating absence of multiple forms (Figure 5). The summary of purification procedures is presented in Table 8 . The overall level of recovery was $32.52 \%$ while 44.61 -fold purification of xylanase was achieved with specific activity of $493.48 \mathrm{Umg}^{-1}$. The purified enzyme showed a single protein band on SDS-PAGE indicating its monomeric nature with molecular weight $\sim 31.5 \mathrm{kDa}$ (Figure 6). The molecular weight of xylanase of the other xylanolytic microorganisms such as Streptomyces chartreusis L1105, Streptomyces sp. QG-11-3, Streptomyces sp B-12-2, S. thermoviolaceus OPC-520 and S. viridisporus T7A were 31.6, 20.5, $23.8-40.5,33-54,59$ and $15-36 \mathrm{kDa}[36,38,42-44]$.

\section{Characterization of the purified xylanase}

Incubation temperature, $\mathrm{pH}$, substrate concentration and substrate specificity: In this study a classical pattern of temperatureactivity relationship with optimum reaction temperature at 55$70^{\circ} \mathrm{C}$ was observed (Figure 7). ESRAA-301097 Xylanase was stable at temperature lower than $85^{\circ} \mathrm{C}$ and retained more than $50 \%$ of its activity after heating at $100^{\circ} \mathrm{C}$ for $1 \mathrm{~h}$. Many investigators reported optimum reaction temperature of 55 to $75^{\circ} \mathrm{C}$ for xylanase activity and stability from other Actinomycetes such as Streptomyces sp. S38, S. chartreusis L1105, Streptomyces sp. Ab106; Streptomyces sp. B-12-2; S. thermoviolaceus OPC-520; S. viridisporus T7A and Streptomyces sp. QG-11-3 [1,36-38,42-44]. On the other hand, the purified xylanase of Streptomyces sp. ESRAA-301097 exhibited maximum activity at $\mathrm{pH} 6.0$ -8.0 with $\mathrm{pH}$ stability over a wide range of $\mathrm{pH}$ ( $\mathrm{pH} 4.0$ - 9.0, Figure 8). The optimum $\mathrm{pHs}$ for xylanolytic activity and stability of $S$. chartreusis, Streptomyces sp. B-12-2, S. thermoviolaceus OPC-520, S. viridisporus T7A and Streptomyces sp. QG-11-3 were 6.7 - 7.7; 6.0 - 7.0; 7.0 -8.0;

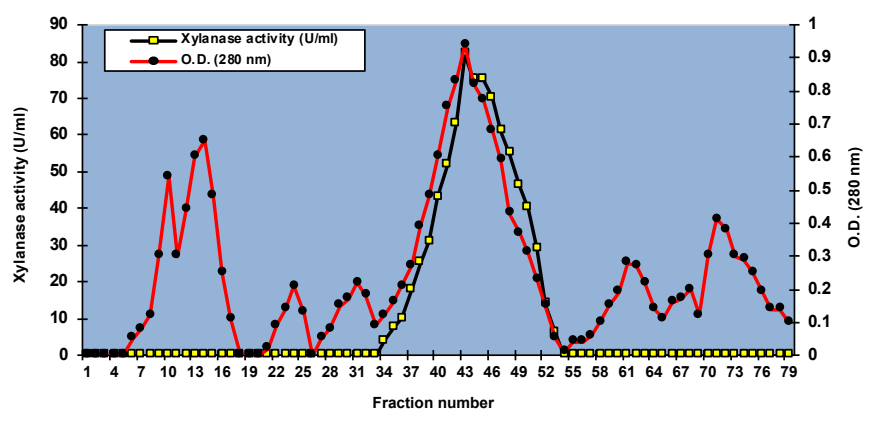

Figure 5: Elution profile of ESRAA-301097 Xylanase on DEAE-cellulose chromatography.

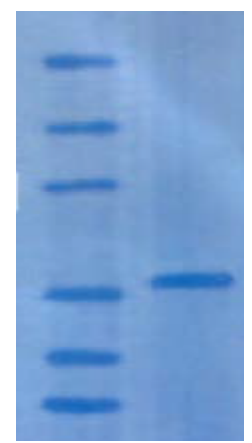

Figure 6: SDS-PAGE analysis of the purified xylanase from Streptomyces sp. ESRAA-301097. Lift lane, standard marker protein $(97.4,66.2,45.0$, 29.0, 20.1 and $14.4 \mathrm{kDa}$ ); right lane, xylanase after Sephadex G-100 column chromatography, which showed a single band.

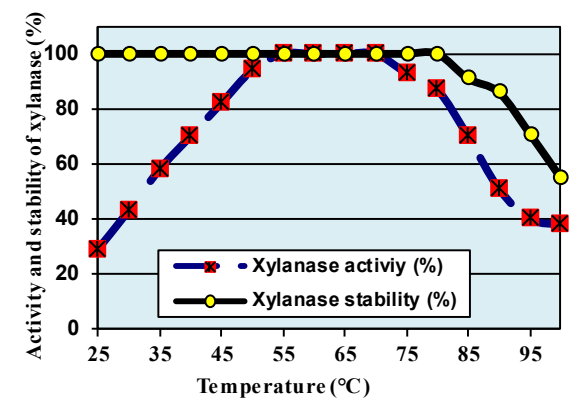

Figure 7: Effect of temperature on xylanase activity and stability of endophytic Streptomyces sp. ESRAA-301097.

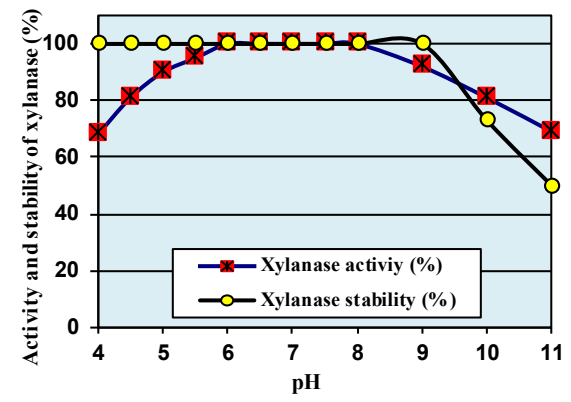

Figure 8: Effect of $\mathrm{pH}$ on xylanase activity and stability of endophytic Streptomyces sp. ESRAA-301097. 
Citation: El-Gendy MMA, El-Bondkly AMA (2014) Optimization of Solid State Fermentation and Leaching Process Parameters for Improvement Xylanase Production by Endophytic Streptomyces sp. ESRAA-301097. J Microb Biochem Technol 6: 154-166. doi:10.4172/19485948.1000137

8.6 and $6.8-7.8$, respectively [36,38,42-44] compared to $\mathrm{pH} 9.0$ for xylanases from S. actuosus A-151, S. olivaceoviridis A1 and Streptomyces sp. Ab106 [37]. Furthermore, xylanase activity was increased with increasing substrate concentration up to $3 \%$ and then abrupt decrease was observed (Table 9) due to the saturation of active sites of the enzyme [44]. The relative activity of xylanase towards different substrates in Table 9 showed higher activity for the highly substituted xylan such as oat spelt xylan (OSX) than less branched birchwood xylan (BWX). These data are corroborated well with the results recorded for xylanases from Streptomyces matenis [14]. ESRAA-301097 xylanase exhibited no specificity towards carboxymethyl cellulose (CMC) and filter paper, which showed that ESRAA-301097 xylanase could be described as cellulose free xylanases. Cellulase-free xylanases is of industrial importance in paper and biobleaching of pulp industries to avoid cellulose degradation as previously reported for cellulase-free xylanases produced by other Streptomyces species $[37,38,42]$.

\section{Evaluation of chemical additives as activators or inhibitors}

Relative to control (no additive), several multivalent metal ions $\mathrm{CO}^{2+}, \mathrm{Mn}^{2+}, \mathrm{Cu}^{2+}, \mathrm{Mg}^{2+}, \mathrm{Zn}^{2+}, \mathrm{Fe}^{3+}, \mathrm{Ba}^{2+}$ and $\left.\mathrm{Ca}^{2+}\right)$ as well as $\mathrm{Na}^{+}$enhanced xylanase activity produced by Streptomyces sp. ESRAA-301097 to $145,152,169,125,138,186,107,111$ and $110 \%$, respectively but $\mathrm{Hg}^{2+}, \mathrm{Cd}^{2+}, \mathrm{Pb}^{2+}, \mathrm{Ni}^{+}$and $\mathrm{Li}^{+}$reduced it to $38,87,90,79$ and $81 \%$, respectively (Table 10). In contrast, xylanases of Streptomyces sp AMT-3 were strongly inhibited by $\mathrm{Cu}^{2+}, \mathrm{Mg}^{2+}$, and $\mathrm{Fe}^{3+}$ [45]. It has been suggested that the effect of metal ions as activators or inhibitors could be attributed to a change in the solubility, the behavior of the ionized nutrients at interfaces and changes in the catalytic properties of the enzyme itself [46]. Table 10 demonstrates that xylanase activity was greatly reduced in $1 \%$ of sodium tripolyphosphate, SDS and sodium tetraborate to 29,41 and $50 \%$, respectively but it was enhanced in the presence of Tween 20, Tween 80 and Triton X-100 to 119,114 and $103 \%$, respectively after $1 \mathrm{~h}$ storage. Whereas 10 and $50 \mathrm{mM}$ of serine protease inhibitors (PMSF) had strong reducing xylanase activity to 21 and $0 \%$, respectively; the inhibitors of cysteine protease (1,10-phenanthroline and Dithiothreitol), thiol protease (iodoacetamide and p-chloromercuribenzoate) and metalloprotease (EDTA and EGTA) at a concentration of 10 and $50 \mathrm{mM}$ had no to minor inhibitory effect on xylanase activity; the enzyme retained (97 and 89\%); (99 and 95\%), (100, 98\%); (100, 100\%); (100, 100\%) and (100 and $96 \%)$ of its activity, respectively. These data revealed that serine not cysteine residues are involved in the catalytic mechanisms of enzyme and it is not metaloproteins or thioproteins but it could be considered as a serine protease [46]. Moreover, effect of such solvent on xylanase activity was varied depending on its polarity. The detected activity of xylanase with 1-Propanol, propyleacetate, benzene, toluene,

\begin{tabular}{|l|l|}
\hline Substrate & Relative activity (\%) \\
\hline concentration \% (Birchwood xylan) & \\
1 & 100 \\
2 & 117 \\
3 & 121 \\
4 & 121 \\
5 & 115 \\
6 & 106 \\
Substrate specificity & 100 \\
Birchwood xylan & 116 \\
Xylan- Oat Spelt & 0 \\
CM-cellulose & 0 \\
Filter paper & \\
\hline
\end{tabular}

Table 9: Impact of substrate concentration and specificity on purified ESRAA-301097 xylanase activity.

\begin{tabular}{|c|c|}
\hline Parameter & Relative activity (\%)* \\
\hline Control (without additives) & 100 \\
\hline $\begin{array}{l}\text { Metal additives (10 mM) } \\
\mathrm{Co}^{2+}\end{array}$ & 145 \\
\hline $\mathrm{Mn}^{2+}$ & 152 \\
\hline $\mathrm{Cu}^{2+}$ & 169 \\
\hline $\mathrm{Mg}^{2+}$ & 125 \\
\hline $\mathrm{Zn}^{2+}$ & 138 \\
\hline $\mathrm{Fe}^{3+}$ & 186 \\
\hline $\mathrm{Na}^{+}$ & 110 \\
\hline $\mathrm{Ba}^{2+}$ & 107 \\
\hline $\mathrm{Hg}^{2+}$ & 38 \\
\hline $\mathrm{Cd}^{2+}$ & 87 \\
\hline $\mathrm{Pb}^{2+}$ & 90 \\
\hline $\mathrm{Ca}^{2+}$ & 111 \\
\hline $\mathrm{Ni}^{+}$ & 79 \\
\hline $\mathrm{Li}^{+}$ & 81 \\
\hline \multicolumn{2}{|l|}{ Detergent additives (1\%) } \\
\hline Tween 20 & 119 \\
\hline Tween 80 & 114 \\
\hline Triton X-100 & 103 \\
\hline Sodium dodecyl sulphate (SDS) & 41 \\
\hline Sodium tripolyphosphate & 29 \\
\hline Sodium tetraborate & 50 \\
\hline \multirow{2}{*}{\multicolumn{2}{|c|}{$\begin{array}{l}\text { Protease inhibitors (mM) } \\
\text { Paramethyl sulfonyl fluoride (PMSF) }\end{array}$}} \\
\hline & \\
\hline 10 & 21 \\
\hline 50 & 0 \\
\hline \multicolumn{2}{|l|}{ p-Chloromercuribenzoate (PCMB) } \\
\hline 10 & 100 \\
\hline \multirow{2}{*}{\multicolumn{2}{|c|}{ lodoacetamide }} \\
\hline & \\
\hline 10 & 100 \\
\hline 50 & 98 \\
\hline \multicolumn{2}{|l|}{ 1,10- Phenanthroline } \\
\hline 10 & 97 \\
\hline 50 & 89 \\
\hline \multicolumn{2}{|l|}{ Dithiothreitol ( DTT) } \\
\hline 10 & 99 \\
\hline 50 & 95 \\
\hline \multicolumn{2}{|l|}{ EDTA } \\
\hline 10 & 100 \\
\hline 50 & 100 \\
\hline \multicolumn{2}{|l|}{ EGTA } \\
\hline 10 & 100 \\
\hline 50 & 96 \\
\hline \multicolumn{2}{|l|}{ Organic solvents $(50 \%)$} \\
\hline 1-Propanol & 49 \\
\hline Propyleacetate & 70 \\
\hline Benzene & 111 \\
\hline Toluene & 90 \\
\hline n-Hexane & 109 \\
\hline Decanol & 94 \\
\hline Isooctane & 100 \\
\hline Tetradecane & 102 \\
\hline n-Hexadecane & 108 \\
\hline Ethyl acetate & 60 \\
\hline
\end{tabular}

${ }^{*}$ One hundred percent (\%) was assigned to the activity in the absence of these chemical additives

Table 10: Some factors affecting xylanase activity produced by Streptomyces sp. ESRAA-301097.

n-Hexane, decanol, isooctane, tetradecane, n-Hexadecane and ethyl acetate were found to be $49,70,111,90,109,94,100,102,108$ and $60 \%$, respectively of the control (Table 10). Whereas the increase in activity with non-polar solvents is due to their hydrophobicity properties, decreasing of activity with propyle acetate, propanol and ethyl acetate is attributed to the high polarity of these solvents that stripped the water layer surrounding the enzyme causing enzyme inactivation [47]. Consequently our study clearly indicated that the properties of Streptomyces sp. ESRAA-301097 xylanase make this enzyme potentially very effective and economical for industrial applications. For instance, alcohol -tolerant xylanase is required for biofuel production, solvent 
Citation: El-Gendy MMA, El-Bondkly AMA (2014) Optimization of Solid State Fermentation and Leaching Process Parameters for Improvement Xylanase Production by Endophytic Streptomyces sp. ESRAA-301097. J Microb Biochem Technol 6: 154-166. doi:10.4172/19485948.1000137

and salt tolerant xylanases are applied for bioremediation of solvent contaminated industrial wastewaters, solvent and surfactant tolerant xylanases are used in deinking of recycled paper and solvent tolerance facilitates the selective precipitation, recovery and reuse of enzymes [47].

\section{References}

1. Goswami GK, Pathak R (2013) Microbial xylanases and their biomedica applications: a review. Int J Basic Clin Pharmacol 2: 237-246.

2. Bajaj BK, Abbass $M(2011)$ Studies on an alkali-thermostable xylanase from Aspergillus fumigatus MA28. 3 Biotech 1: 161-171.

3. Ninawe S, Kuhad RC (2005) Use of xylan-rich cost effective agro-residues in the production of xylanase by Streptomyces cyaneus SN32. J Appl Microbiol 99: $1141-1148$

4. Qin S, Li J, Chen HH, Zhao GZ, Zhu WY, et al. (2009) Isolation, diversity, and antimicrobial activity of rare actinobacteria from medicinal plants of tropical rain forests in Xishuangbanna, China. Appl Environ Microbiol 75: 6176-6186.

5. Taechowisan T, Peberdy JF, Lumyong S (2003) Isolation of endophytic Actinomycetes from selected plants and their antifungal activity. World $J$ Microbiol Biotechnol 19: 381-385.

6. El-Bondkly AM, El-Gendy MM (2010) Keratinolytic activity from new recombinant fusant AYA2000, derived from endophytic Micromonospora strains. Can J Microbiol 56: 748-760.

7. El-Bondkly AM, El-Gendy MMA (2012) Cellulase production from agricultural residues by recombinant fusant strain of a fungal endophyte of the marine sponge Latrunculia corticata for production of ethanol. Antonie van Leeuwenhoek 101: 331-346.

8. El-Gendy MMA (2012) Production of glucoamylase by marine endophytic Aspergillus sp. JAN-25 under optimized solid-state fermentation conditions on agro residues. Australian Journal of Basic and Applied Sciences 6: 41-54.

9. El-Bondkly AM (2012) Molecular identification using ITS sequences and genome shuffling to improve 2-deoxyglucose tolerance and xylanase activity of marine-derived fungus, Aspergillus sp. NRCF5. Appl Biochem Biotechnol 167: 2160-2173.

10. Alberton LR, Vandenberghe LP, Assmann R, Fendrich RC, Rodriguéz-León $\mathrm{J}$, et al. (2009) Xylanase production by Streptomyces viridosporus T7A in submerged and solid-state fermentation using agro-industrial residues. Brazilian Archives of Biology and Technology 52: 171-180.

11. Bailey MJ, Biely P, Poutanen K (1992) Interlaboratory testing of methods for assay of xylanase activity. J Biotechnol 23: 257-270.

12. Miller GL (1959) Use of dintrosalicylic acid reagent for determination of reducing sugar. Anal Chem 31: 426-428.

13. Williams ST, Cross T (1971) Actinomycetes. In: Methods in microbiology, vol.4 295-334, Norris JR, Robbins DW (eds), London, Academic Perss, NewYork.

14. Yan QJ, Hao SS, Jiang ZQ, Zhai Q, Chen WW (2009) Properties of a xylanase from Streptomyces matensis being suitable for xylooligosaccharides production. J Molecular Catalyst B: Enzyme 58: 72-77.

15. Szabo IM, Marton M, Buti I, Fermandez C (1975) A diagnostic key for the identification of species of Streptomyces and Streptoverticillium included in the International Streptomyces Project. Acta Bot Acad Sci Hung 21: 387-418.

16. Williams ST, Goodfellow M, Alderson G (1989) Genus Streptomyces Waksman and Henrici 1943, 339AL. In Bergey's Manual of Systematic Bacteriology, vol 4, pp. 2452-2504. Edited by Williams ST, Sharpe ME, Holt JG, Baltimore: Williams \& Wilkins

17. Shirling EB, Gottlieb D (1966) Methods for characterization of Streptomyces species. Int J Syst Bacteriol 16: 313-340.

18. Hasegawa T, Takizawa M, Tanida S (1983) A rapid analysis for chemical grouping of aerobic Actinomycetes. J Gen Appl Microbiol 29: 319-322.

19. Butte W (1983) Rapid method for the determination of fatty acid profiles from fats and oils using trimethylsulphonium hydroxide for transesterification. J Chromatogr 261: 142-145.

20. Lechevalier MP, De-Bievre C, Lechevalier HA (1977) Chemotaxonomy of aerobic Actinomycetes: Phospholipid composition. Biochem. Syst Ecol 5: 249-260.
21. Minnikin DE, Patel PV, Alshamaony L, Goodfellow M (1977) Polar lipid composition in the classification of Streptomyces and related bacteria. Int $J$ Syst Bacteriol 27: 104-117.

22. Mandel M, Marmur J (1968) Use of ultraviolet absorbance-temperature profile for determining the guanine plus cytosine content of DNA. Methods Enzymo 12B: 195-206.

23. Lane DL (1991) 16S/23S rRNA sequencing. In: Stackebrandt E, Goodfellow M. (Eds.), Nucleic Acid Techniques in Bacterial Systematics, Wiley, New York, 115-175.

24. El-Bondkly AM, El-Gendy MM, Bassyouni RH (2012) Overproduction and biological activity of prodigiosin-like pigments from recombinant fusant of endophytic marine Streptomyces species. Antonie Van Leeuwenhoek 102 719-734.

25. Smith PK, Krohn RI, Hermanson GT, Mallia AK, Gartner FH, et al. (1985 Measurement of protein using bicinchoninic acid. Anal Biochem 150: 76-85.

26. Laemmli UK (1970) Cleavage of structural proteins during the assembly of the head of bacteriophage T4. Nature 227: 680-685

27. Sheded MG, Pulford ID, Hamed AI (2006) Presence of major and trace elements in seven medicinal plants growing in the South-Eastern Desert, Egypt. Journal of Arid Environments 66: 210-217.

28. El-Massry KF, El-Ghorab AH, Farouk A (2002). Antioxidant activity and volatile components of Egyptian Artemisia judaica L. Food Chemistry 79: 331-336.

29. Hosseinzadeh H, Karimi GR, Ameri M (2002) Effects of Anethum graveolens L. seed extracts on experimental gastric irritation models in mice. BMC Pharmacol 2: 21.

30. Li CJ, Huang SY, Wu MY, Chen YC, Tsang SF, et al. (2012) Induction of apoptosis by ethanolic extract of Corchorus olitorius leaf in human hepatocellular carcinoma (HepG2) cells via a mitochondria-dependent pathway. Molecules 17: 9348-9360.

31. Suryanarayanan TS, Murali TS, Venkatesan G (2002) Occurrence and distribution of fungal endophytes in tropical forests across a rainfall gradient Can J Bot 80: 818-826.

32. Kuester E, Williams ST (1964) Selection of Media for Isolation of Streptomycetes Nature 202: 928-929.

33. Kim SB, Lonsdale J, Seong CN, Goodfellow M (2003) Streptacidiphilus gen nov., acidophilic actinomycetes with wall chemotype I and emendation of the family Streptomycetaceae (Waksman and Henrici (1943)AL) emend. Rainey et al. 1997. Antonie Van Leeuwenhoek 83: 107-116.

34. Manfio GP, Zakrzewska-Czerwinska J, Atalan E, Goodfellow M (1995) Towards minimal standards for the description of Streptomyces species. Bioteknologia 7-8: 242-253

35. Sonia KG, Chadha BS, Saini HS (2005) Sorghum straw for xylanase hyper-production by Thermomyces lanuginosus (D2W3) under solid-state fermentation. Bioresour Technol 96: 1561-1569.

36. Li X, Sun B, Zhao J, Lv Y, Song H, et al. (2011) Production and improved bleaching abilities of a thermostable xylanase from a newly isolated Streptomyces chartreusis strain. African Journal of Biotechnology 10: 14132 14142.

37. Techapun C, Charoenrat T, Poosaran N, Watanabe M, Sasak K (2002) Thermostable and alkaline-tolerant cellulase-free xylanase produced by thermotolerant Streptomyces sp. Ab106. J Biosci Bioeng 93: 431-433.

38. Beg QK, Bhushan B, Kapoor M, Hoondal GS (2000) Enhanced production of a thermostable xylanase from Streptomyces sp. QG-11-3 and its application in biobleaching of eucalyptus kraft pulp. Enzyme Microb Technol 27: 459-466.

39. Abd El-Nasser NH, Ali AM, Keera AA (2010) Xylanase production by Streptomyces Lividans and its application on waste paper. AJBAS 4: 13581368

40. Sharma P, Bajaj BK (2005) Production and partial characterization of alkalitolerant xylanase from an alkalophilic Streptomyces species CD3. Journal of Scientific and Industrial Research 64: 688-697.

41. Kapoor M, Nair LM, Kuhad RC (2008) Cost effective xylanase production from free and immobilized Bacillus pumilus strain MK001 and its application in saccharification of Prosopis juliflora. Biochemical Engineering 38: 88-97. 
Citation: El-Gendy MMA, El-Bondkly AMA (2014) Optimization of Solid State Fermentation and Leaching Process Parameters for Improvement Xylanase Production by Endophytic Streptomyces sp. ESRAA-301097. J Microb Biochem Technol 6: 154-166. doi:10.4172/19485948.1000137

42. Elegir G, Sykes M, Jeffries TW (1995) Differential and synergistic action of Streptomyces endoxylanases in prebleaching of kraft pulp. Enzyme Microb Technol 17: 954-959.

43. Tsujibo H, Miyamoto K, Kuda T, Minami K, Sakamoto T, et al. (1992) Purification, properties, and partial amino acid sequences of thermostable xylanases from Streptomyces thermoviolaceus OPC-520. Appl Environ Microbiol 58: 371-375.

44. Magnuson TS, Crawford DL (1997) Purification and characterization of an alkaline xylanase from Streptomyces viridosporus T7A. Enzyme and Microbial Technology 21: 160-164.
45. Nascimento RP, Coelho RR, Marques S, Alves L, Gírio FM, (2002) Production and partial characterisation of xylanase from Streptomyces sp. strain AMT-3 isolated from Brazilian cerrado soil. Enzyme Microbial Technol 31: 549-555.

46. Rao MB, Tanksale AM, Ghatge MS, Deshpande VV (1998) Molecular and biotechnological aspects of microbial proteases. Microbiol Mol Biol Rev 62: 597-635.

47. Woldesenbet F, Gupta N, Sharma, P (2012) Statistical optimization of the production of a cellulase-free, thermo-alkali-stable, salt-and solvent tolerant xylanase from Bacillus halodurans by SSF. Archives of Applied Science Research 4: 524-35. 